\title{
FAURIEA, A NEW GENUS OF THE LECANOROID CALOPLACOID LICHENS (TELOSCHISTACEAE, LICHEN-FORMING ASCOMYCETES)
}

\author{
S. Y. Kondratyuk ${ }^{1 *}$, L. Lő́ö̈s ${ }^{2}$, J. A. Kim³ ${ }^{3}$, A. S. Kondratiuk ${ }^{3,4}$, M.-H. Jeong ${ }^{3}$ \\ S. H. JANG ${ }^{3}$, S.-O. $\mathrm{OH}^{3}$, X. Y. WANG ${ }^{5}$ and J.-S. Hur ${ }^{3}$ \\ ${ }^{1}$ M. H. Kholodny Institute of Botany, Tereshchenkivska str. 2, 01004 Kiev, Ukraine \\ *E-mail: ksya_net@ukr.net \\ ${ }^{2}$ Department of Botany, Hungarian Natural History Museum \\ H-1431 Budapest, Pf. 137, Hungary \\ ${ }^{3}$ Korean Lichen Research Institute, Sunchon National University \\ Sunchon 540-742, Republic of Korea, E-mail: jshur1@sunchon.ac.kr \\ ${ }^{4}$ Institute of Biology, Scientific Educational Centre, Taras Shevchenko National University \\ of Kiev, Volodymyrska str. 64/13, 01601 Kiev, Ukraine \\ ${ }^{5}$ Laboratory for Plant Diversity and Biogeography of East Asia, Kunming Institute of Botany \\ Chinese Academy of Sciences, Kunming, China
}

(Received 15 May, 2016; Accepted 10 July, 2016)

The robust monophyletic branch having the highest level of bootstrap support in the phylogenetical tree of the Teloschistaceae based on combined data set of ITS, LSU nrDNA and 12S SSU mtDNA sequences, which does not belong to any other earlier proposed genera of the subfamily Caloplacoideae, is described as the new genus Fauriea S. Y. Kondr., L. Lőkös et J.-S. Hur, gen. nova for lecanoroid South Korean Caloplaca chujaensis, and newly described Eastern Chinese Fauriea orientochinensis. Descriptions of the new genus Fauriea and the species Fauriea orientochinensis, a comparison with closely related taxa and a discussion of their position are provided. New name Tayloriellina is proposed for the genus of the subfamily Brownlielloideae Tayloriella S. Y. Kondr., Kärnefelt, A. Thell, Elix et Hur (nom. illeg., non Tayloriella Kylin, Rhodomebaceae, Rhodophyta). New combinations for type species of the genera Fauriea and Tayloriellina (i.e.: Fauriea chujaensis (basionym: Caloplaca chujaensis S. Y. Kondr., L. Lőkös et J.-S. Hur), and Tayloriellina erythrosticta (basionym: Lecanora erythrosticta Taylor)) are proposed. Fauriea chejuensis and Biatora pseudosambuci are for the first time recorded for China.

Key words: Biatora pseudosambuci, Caloplacoideae, Fauriea, Fauriea orientochinensis

\section{INTRODUCTION}

Taxonomy of the Teloschistaceae has dramatically changed since 2012 based on molecular phylogeny (Arup et al. 2013a, Fedorenko et al. 2012, Gaya et al. 2012, 2015, Kondratyuk et al. 2013a, b, 2014a, b, 2015b, c, d). Three subphyla, i.e. subfamilies Teloschistoideae, Caloplacoideae and Xanthorioideae proposed in 2012-2013 years (Arup et al. 2013b, Gaya et al. 2012) are recently added by new one, i.e. subfamily Brownlielloideae (Kondratyuk et al. 2015b). 
Number of accepted genera of the Teloschistaceae evolved from 10 in Kärnefelt (1989) to 29 (Arup et al. 2013a), and to 80 (see Kondratyuk et al. $2015 d)$. New genera of the Teloschistoid and Xanthorioid lichens are also recently described (Søchting et al. 2014a, b, Kondratyuk et al. 2015d).

The aim of this paper is to provide legal description for robust monophyletic group of the subfamily Caloplacoideae, which does not belong to any other earlier described genera of this subfamily. The new genus Fauriea for the Eastern Asian species Caloplaca chujaensis, and the newly described Eastern Chinese species Fauriea orientochinensis are proposed, as well as the new name Tayloriellina for the genus of the subfamily Brownlielloideae and the new combination for its type species are provided.

\section{MATERIAL AND METHODS}

Specimens were examined using standard microscopical techniques, i.e. hand-sectioning under Nikon SMZ-645 dissecting microscope (Nikon Corp., Tokyo, Japan), sections were observed under Nikon E-200 and Olympus BX51 microscope (same as above). Spot test reactions were performed on thalli under a compound microscope. Chemicals were extracted in analytical grade acetone in a $1 \mathrm{~mL}$ Eppendorf tube. Thin layer chromatography (TLC) was performed using a glass plate coated with TLC Silica gel 60, in solvent system A (toluene : dioxin : acetic acid = 180:45:5) (Orange et al. 2010).

Total DNA was extracted directly from the thalli according to Ekman (1999) and was purified with DNeasy Plant Mini Kit (QIAGEN, Germany). The nuclear ribosomal RNA gene region including the internal transcribed spacers 1 and 2 and the 5.8S subunit (ITS) was amplified using the primers ITS1F (Gardes and Bruns 1993) and ITS4 (White et al. 1990), the 28S LSU using the primer LR5 (Vilgalys and Hester 1990), and the 12S mtSSU using the primers mtSSU1-mtSSU3R and mtSSU2R (Fedorenko et al. 2009, 2012).

The amplification was done using a Takara JP/TP600 PCR machine (Takara Bio Inc., Japan). One initial cycle of $5 \mathrm{~min}$ at $94{ }^{\circ} \mathrm{C}$ was followed by 30 cycles of the following steps: 30 seconds at $94{ }^{\circ} \mathrm{C}, 39$ seconds at $57{ }^{\circ} \mathrm{C}$ and $1 \mathrm{~min}$ at $72{ }^{\circ} \mathrm{C}$. Amplifications were ended with a final cycle at $72{ }^{\circ} \mathrm{C}$ for 10 min. PCR products were then sent to the sequencing facilities of the Genotech Cooperation, Seoul, South Korea for cleaning and sequencing. The sequencing was carried out using the fluorescent marker BigDye and an ABI 3730xl sequencing machine (Applied Biosystems, Carlsbad, CA, USA).

The consensus sequence was aligned with all related species sequences retrieved from the GenBank database (Table 1). The consensus sequences were then deposited into GenBank under the accession numbers KX793095KX793103. Phylogenetical analysis was performed using the ITS region and 
LSU gene of nrDNA and 12S SSU mtDNA sequences of the treated fungi retrieved from the GenBank database and the 5 lichen-forming fungi investigated in this study. Sequence alignment was conducted in BioEdit and a phylogenetical tree was generated by the maximum parsimony (MP), minimum evolution (ME), and maximum likelihood (ML) analysis methods performed in Mega 5.0 (Tamura et al. 2011) with the number of bootstrap trials set to 1,000 .

Nine sequences on nrDNA and mtDNA are for the first time submitted to GenBank for the following taxa: Fauriea chujaensis and F. orientochinensis.

\section{RESULTS AND DISCUSSION \\ Description of taxa}

Fauriea S. Y. Kondr., L. Lőkös et J.-S. Hur, gen. nova

Mycobank no.: MB 817961

Thallus crustose, continuous; grey to whitish grey or lead-grey in places; apothecia seem to be lecanorine, immersed into thallus to semi-immersed, disc dark brown, true exciple scleroplectenchymatous to mesodermatous paraplectenchymatous, cortical layer paraplectenchymatous; ascospores bipolar. Conidiomata not seen. Thallus and epihymenium K-; anthraquinones absent.

Type species: Fauriea chujaensis (S. Y. Kondr., L. Lőkös et Hur) S. Y. Kondr., L. Lőkös, J. Kim, A. S. Kondratiuk, S.-O. Oh et J.-S. Hur.

Thallus crustose, continuous/entire (not areolate); grey to whitish grey or lead-grey in places; with of Lecanora type apothecia with brown or dark brown disc. Hypothallus black or absent. Apothecia at first immersed into thallus, later semi-immersed or seen in thalline warts, seem to be lecanorine, to sunken into the thallus, true lecanorine; thalline margin whitish grey, disc dark brown, true margin if developed entire, light brown or transparent brown; in section true exciple scleroplectenchymatous to mesodermatous paraplectenchymatous; cortical layer of thalline exciple paraplectenchymatous; paraphyses broom-like branched, the uppermost portions becoming brownish; asci 8-spored; bipolar ascospores narrowly ellipsoid, slightly widened at the septum; ascospore septum of medium width. Conidiomata not seen. Chemistry: thallus and epihymenium $\mathrm{K}$-; anthraquinones absent.

Ecology: On siliceous rocks in the coastal zone, often growing together with other members of the genus Caloplaca (C. yeosuensis S. Y. Kondr. et J.S. Hur, C. aff. diffluens (Hue) Zahlbr., C. sideritis (Tuck.) Zahlbr.), as well as 
members of the genera Lecanora, Ramalina, Phaeophyscia, etc., or on bark of Pinus trees, where often associated with Amandinea punctata (Hoff.) Coppins et Scheid. and Biatora pseudosambuci (S. Y. Kondr., L. Lőkös et Hur) S. Y. Kondr. (see Kondratyuk et al. 2016).

Distribution: So far it is known from several collections from islands and coastal part of mainland of South Korea and Eastern China. Fauriea chujaensis (as well as Biatora pseudosambuci) is for the first time recorded from China here.

Etymology: It is named after the known French botanist Urbain Jean Faurie (1847-1915), who provided important collections of lichens, mosses and vascular plants of the Eastern Asian region.

Taxonomic notes: The genus Fauriea is positioned in one clade with the genus Rufoplaca Arup, Søchting et Frödén and the Caloplaca furax group. However, this clade has very weak support, while the two mentioned genera and the Caloplaca furax group have shown very high level of bootstrap support, as after ITS nrDNA, mtDNA sequences, as well as after combined data set (Fig. 3). Unfortunately we were not able to include into our analysis recently described Caloplaca lecapustulata Aptroot et M. Cáceres and C. lecanorocarpa Aptroot et M. Cáceres, because there no data on nrLSU and $\mathrm{mtSSU}$ sequences so far available. However, it should be mentioned that after our phylogenetical analysis these two species show the closest relation (as being sister branch) to the genus Huneckia, as it was shown by Aptroot and Cáceres (2016). However, after including these data to our matrix, unexpectedly the Faureria clade forms sister branch to these two branches as well. However, as it was emphasised above the position of the two lecanoroid species (Caloplaca lecapustulata Aptroot et M. Cáceres and C. lecanorocarpa) in the subfamily Caloplacoideae is hitherto confirmed only by nrITS data.

Macroscopically the representatives of the genus Fauriea is similar to some species of the genus Pyrenodesmia, i.e. P. variabilis (Pers.) A. Massal., a Northern Hemisphere lichen growing on calcareous rocks. However, Fauriea chujaensis differs from Pyrenodesmia variabilis in having continuous/entire thallus, in having smaller apothecia, in having narrower ascospores, and in having much wider ascospore septum, as well as in the lack of the white pruina on apothecium discs and in the lack of $\mathrm{K}+$ and $\mathrm{C}+$ reactions of thallus and epihymenium (see also Kondratyuk et al. 2015a).

Unfortunately there are hitherto no molecular data on 'Caloplaca' atroalba (Tuck.) Zahlbr., a North American lichen growing on non-calcareous or calcareous rocks in having crustose, grey thallus without asexual propagules and brown apothecium discs, to which Fauriea chujaensis is similar. However, Fauriea chujaensis differs from Caloplaca atroalba in having only grey and continuous/entire crustose thallus, in having smaller apothecia, and in having 
smaller and especially much narrower ascospores, and in having much wider ascospore septum, as well as in the lack of $\mathrm{K}+$ and $\mathrm{C}+$ reactions of thallus and epihymenium.

After having mainly immersed or semi-immersed apothecia Fauriea chujaensis may resemble to some species of the genus Aspicilia A. Massal., but microscopical study of ascospores easily confirms its position in the family Teloschistaceae.

Fauriea chujaensis is similar to Caloplaca sideritis with which it sometimes grows side by side, in having similar greyish crustose thallus and lecanorine apothecia with dark grey or grey thalline margins, but it differs from C. sideritis in the lack of yellowish apothecium disc and in the lack of $\mathrm{K}+$ and $\mathrm{C}+$ reaction of epithecium and thalline cortical layer.

From species of the genus Lecanora Ach. with which Fauriea chujaensis often growing side by side it differs in having immersed to semi-immersed (not constricted at the basis when uplifted in thalline warts) apothecia, in having black hypothallus, as well as in having Teloschistes-type of asci and bipolar ascospores.

Fauriea orientochinensis S. Y. Kondr., X. Y. Wang et J.-S. Hur, sp. nova (Figs 1-2)

Mycobank no.: MB 817962

Similar to Fauriea chujaensis, but differs in having much thicker while smaller, thallus, in having more often prominent and more regularly developed usually lecanorine apothecia, in having better developed thalline margin, in having lower cortical layer of thallus and thalline exciple, in having higher hymenium, in having thicker and lacking oil subhymenium, and in having longer ascospores and in having epiphyte substrate.

Type: China, Shandong Prov., Rongcheng Co., Mt Chengshantou, on Pinus bark, growing together with Amandinea punctata. Lat.: $37^{\circ} 25^{\prime} 03.0^{\prime \prime} \mathrm{N}$; Long.: $122^{\circ} 40^{\prime} 38.3^{\prime \prime}$ E; Alt.: $20 \mathrm{~m}$ a.s.l. Coll.: Wang, X. Y. and Hur, J.-S. (CH110011), 18.07.2011 (KoLRI 013954 sub Fauriea orientochinensis - holotype); the same locality, growing as small addition among Amandinea punctata thalli, (CH-110015), (KoLRI 013957 sub Fauriea orientochinensis - isotype); the same locality, growing with Biatora pseudosambuci, (CH-110017), (KoLRI 013959 sub Fauriea orientochinensis - isotype).

Thallus to $0.5-3 \mathrm{~cm}$ across, but may form larger aggregations; crustose, continuous/entire (not areolate), whitish grey to light grey or somewhat dirty 
whitish grey, often with dust particles and aerophytic algae, very uneven owing to substrate surface (Pinus tree bark), from very thin in the peripheral portion to rather thick, distinctly wrinkled in the centre; often badly seen in the centre owing to the numerous lecanorine apothecia with dull dark brown to dark violetish brown discs. Thallus in section to $250(-350) \mu \mathrm{m}$ thick, cortical layer somewhat indistinct, while epinecral layer to $10 \mu \mathrm{m}$ thick more or less regularly present; algal zone to $40-70 \mu \mathrm{m}$ thick, algal cells to $9-19(-22) \mu \mathrm{m}$ in diam. Hypothallus not observed.

Apothecia (0.3-)0.5-0.7(-1) $\mathrm{mm}$ in diam., and to $0.4 \mathrm{~mm}$ thick, but often mainly small to $0.4(-0.5) \mathrm{mm}$ in diam, lecanorine, rarely zeorine (see only at the largest magnification) (within the same thallus), immersed into thallus and very indistinct, irregularly rounded, crowded at first, only a few apothecia per thallus seem to be sessile, but still sunken into the thallus and while; thalline margin white grey or light grey, almost not uplifted above the level of thallus and very indistinct at first later better seen and slightly uplifted above the level of thallus, concolorous with thallus, seems to be variable in thickness, while $0.08-0.12 \mathrm{~mm}$ thick, usually permanent; disc plane or slightly concave, rarely somewhat semi-convex or undulating, dull brown to dark brown or violet brown within the same thallus; in section thalline exciple to 60-80 $\mu \mathrm{m}$ thick, with cortical layer to $10-15 \mu \mathrm{m}$ thick, paraplectenchymatous, cell lumina to $4-5 \mu \mathrm{m}$ in diam., often with considerable portion of epinecral layer in places, sometimes outermost layer slightly brownish; true exciple to $15-20 \mu \mathrm{m}$ thick in lateral and basal portion, rarely to $40(-70) \mu \mathrm{m}$ wide in the uppermost lateral portion, Blastenia-type (i.e. consisting of radiating hyphae); hymenium to 100-110 $\mu \mathrm{m}$ high, hyaline; epihymenium to $20-30 \mu \mathrm{m}$ thick, yellowish brown, paraphyses almost unswollen towards the tips to $2.5-3.5 \mu \mathrm{m}$ in diam., in the upper portion becoming distinctly yellowish-brownish or straw light brownish; subhymneium to 100-130 $\mu \mathrm{m}$ thick, hyaline or straw or light brownish in places, without oil; asci 8-spored; ascospores widely ellipsoid to widely fusiform, sometimes with more or less attenuated ends, (10-)12-15($16) \times 5-6(-7) \mu \mathrm{m}$ in water and somewhat becoming larger in $\mathrm{K},(8-) 11-16(-17)$ $\times(4-) 4.5-6(-7) \mu \mathrm{m}$; ascospore septum 3-5 $\mu \mathrm{m}$ thick in water and becoming wider to $4-7 \mu \mathrm{m}$ wide in $\mathrm{K}$.

Chemistry: Thallus, true exciple and epihymenium $\mathrm{K}-$, while the yellowish-brownish upper portion of paraphyses becoming better seen in $\mathrm{K}$.

Ecology: On bark of Pinus trees.

Distribution: So far it is known only from the type locality in China, Eastern Asia.

Etymology: Species epithet refers to the eastern part of China, where the type collection was done. 

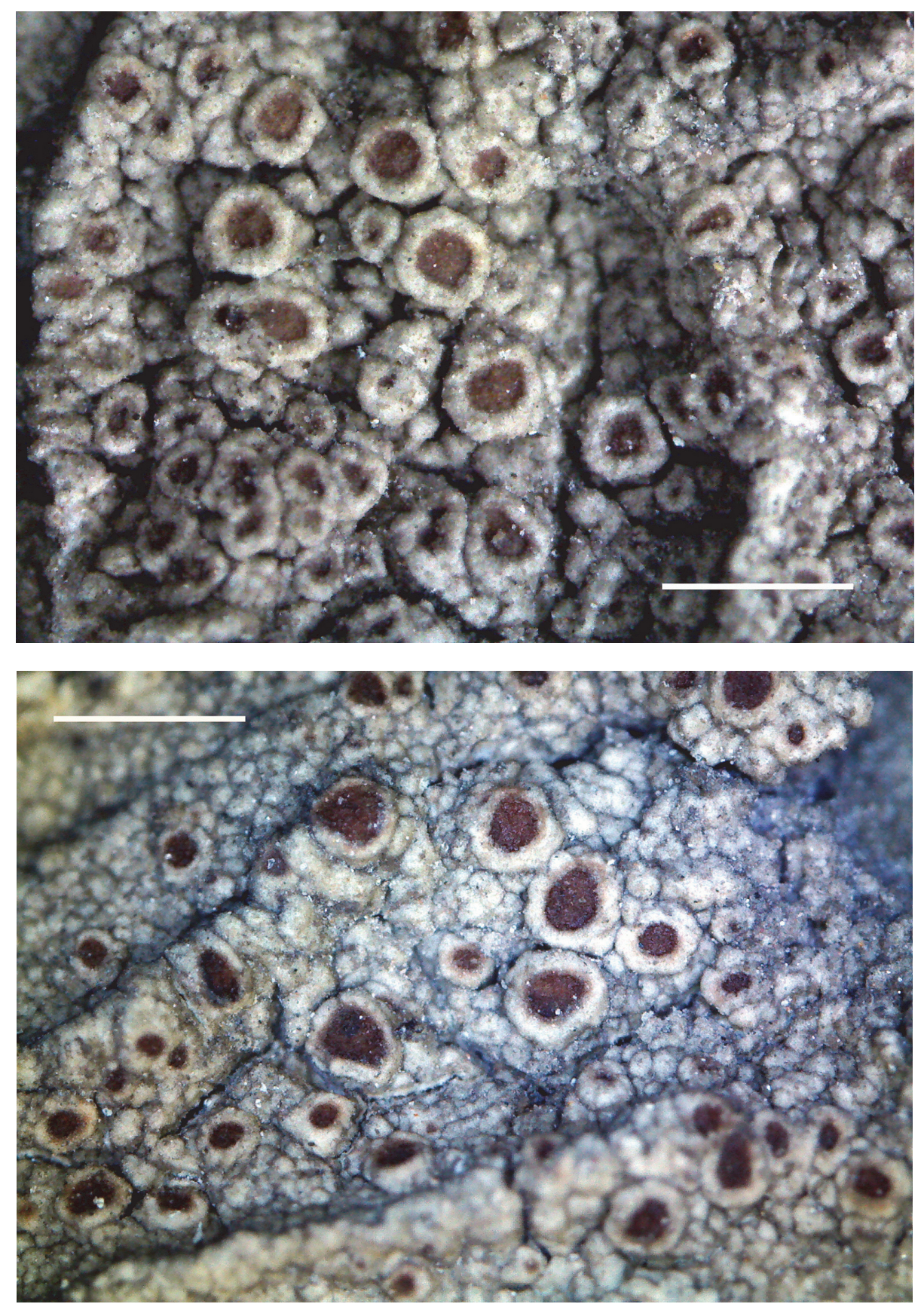

Fig. 1. Fauriea orientochinensis (holotype), general habit. Scale: $1 \mathrm{~mm}$ (photo: S. Kondratyuk) 

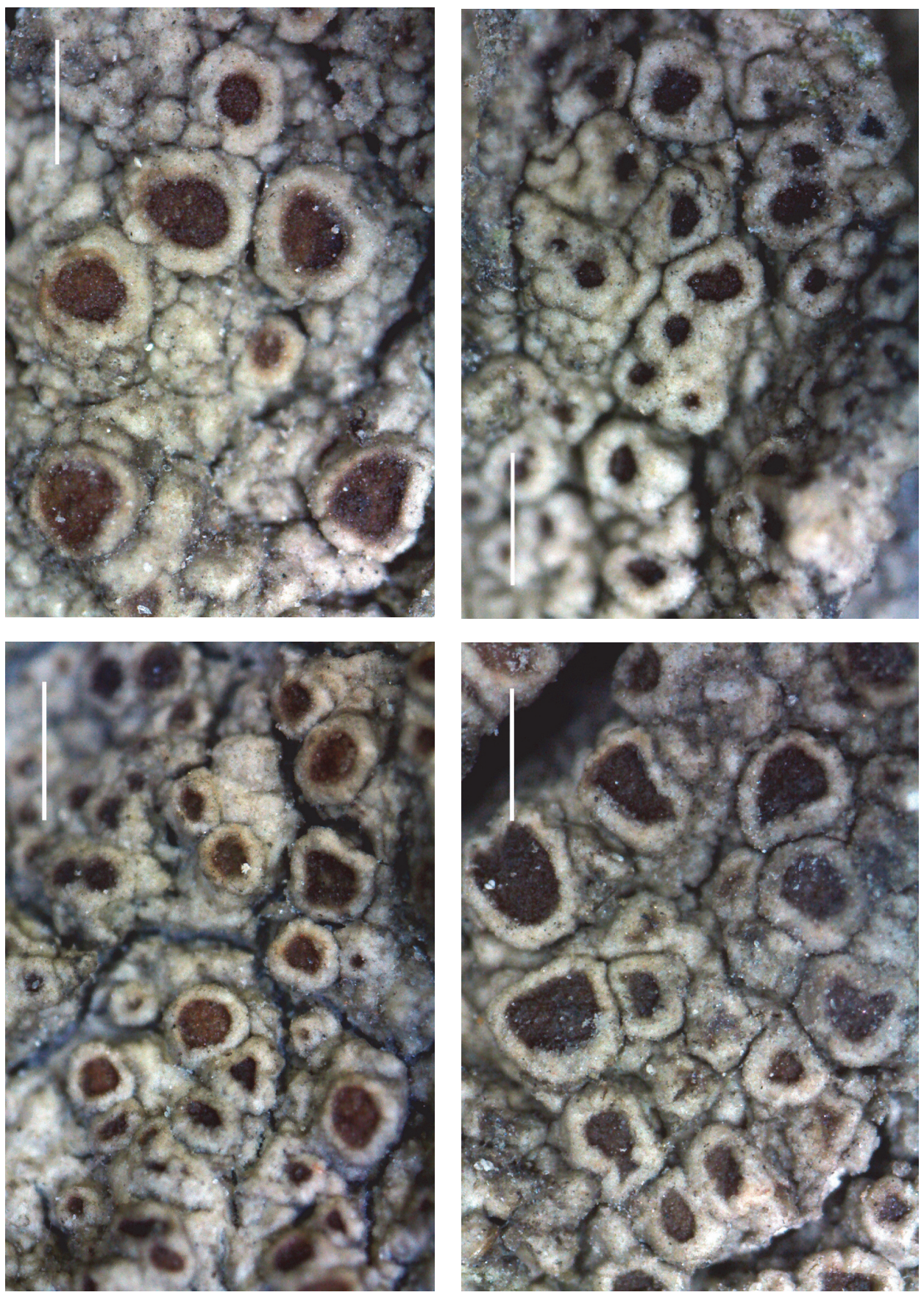

Fig. 2. Fauriea orientochinensis (holotype) enlarged portion of thallus with lecanorine apothecia. Scale: $0.5 \mathrm{~mm}$ (photo: S. Kondratyuk) 
Taxonomic notes: Fauriea orientochinensis is similar to F. chujaensis S. Y. Kondr., L. Lökös et J.-S. Hur, very common in South Korea, Eastern Asia species growing on siliceous rocks in coastal zone of islands and mainland of this country, in having crustose, continuous/entire (not areolate) thallus, and in having numerous Lecanora-type apothecia with brown or dark brown disc apothecia not being constricted at the basis, but differs in having much thicker while smaller $(0.5-3 \mathrm{~cm}$ vs. or 3-5 cm across or more) thallus, in having more often prominent and more regularly developed usually lecanorine apothecia (only sometimes being zeorine), in having better developed thalline margin, in having lower cortical layer of thallus and thalline exciple (to $10 \mu \mathrm{m}$ vs. 20$25 \mu \mathrm{m}$ thick), in having higher hymenium (100-110 $\mu \mathrm{m}$ vs. 70-80 $\mu \mathrm{m}$ high), in having thicker and lacking oil subhymenium (100-130 $\mu \mathrm{m}$ vs. 50-60 $\mu \mathrm{m}$ thick, with oil droplets), and in having longer ascospores $((10-) 12-15(-16) \times 5-6(-7)$ $\mu \mathrm{m}$ vs. (8-)11-13(-16) × (5-)5.5-6(-7) $\mu \mathrm{m})$ and in epiphyte substrate.

Similarly to Fauriea chujaensis apothecia of F. orientochinensis are almost sunken into the thallus, not sessile, mainly not well defined, sometimes as regularly rounded typical of the Lecanora subfuscata type. Only rarely and only at the highest magnification apothecia found to be zeorine, where true exciple dull light brownish, and disc dark brown.

Table 1

Specimens included in the phylogenetical analysis with GenBank numbers

\begin{tabular}{|c|c|c|c|c|}
\hline Species name & Voucher details / references & ITS & LSU & mt DNA \\
\hline Blastenia crenularia & Gaya et al. (2012) & JQ301711 & & JQ301489 \\
\hline Blastenia ferruginea & & KC179416 & KC179163 & KC179493 \\
\hline Blastenia subochracea & Arup et al. (2013a) & KC179418 & & \\
\hline Brigantiaea ferruginea & SK779, Kondratyuk et al. (2013b) & KF264622 & & KF264684 \\
\hline Brigantiaea ferruginea & SK780, Kondratyuk et al. (2013b) & KF264623 & & KF264685 \\
\hline Bryoplaca jungermanniae & Arup et al. $(2013 a)$ & KC179420 & & \\
\hline Bryoplaca sinapisperma & Arup et al. (2013a) & KC179421 & & KC179495 \\
\hline Bryoplaca tetraspora & Arup et al. (2013a) & KC179422 & & \\
\hline Caloplaca cerina & $\begin{array}{l}\text { FNM185, Fedorenko et al. } \\
(2009,2012)\end{array}$ & EU681284 & & EU680863 \\
\hline Caloplaca cerina & Gaya et al. (2012) & & JQ301549 & \\
\hline 'Caloplaca' furax & & HQ644341 & & \\
\hline 'Caloplaca' furax & Gaya et al. (2012) & JQ301622 & & \\
\hline Caloplaca pelodella & SK714, Kondratyuk et al. (2013b) & KF264629 & & KF264689 \\
\hline 'Caloplaca' phaeothamnos & & JN813419 & & \\
\hline Caloplaca stillicidiorum & Gaya et al. (2008) & EU639607 & & \\
\hline Caloplaca thracopontica & & HM538525 & & \\
\hline Eilifdahlia dahlii & SK956, Kondratyuk et al. (2014a) & KJ021221 & KJ021252 & KJ021277 \\
\hline Eilifdahlia dahlii & SK959, Kondratyuk et al. (2014a) & KJ021318 & KJ021253 & KJ021279 \\
\hline Eilifdahlia wirthii & SK262, Kondratyuk et al. (2014a) & KJ021319 & KJ021254 & KJ021280 \\
\hline Elenkiniana ehrenbergii & Søchting and Figueras (2006) & DQ888715 & & \\
\hline Elenkiniana gloriae & SK750, Kondratyuk et al. (2014a) & KJ021323 & & \\
\hline
\end{tabular}


Table 1 (continued)

\begin{tabular}{|c|c|c|c|c|}
\hline Species name & Voucher details / references & ITS & LSU & mt DNA \\
\hline Elenkiniana gloriae & SK611, Kondratyuk et al. (2014a) & KJ021321 & KJ021256 & KJ021282 \\
\hline Elenkiniana gloriae & SK613, Kondratyuk et al. $(2014 a)$ & KJ021322 & & KJ021283 \\
\hline Fauriea orientochinensis & SK709, China, CH 110017 & & & \\
\hline & KoLRI 013959 & KX793095 & KX793098 & KX793101 \\
\hline auriea orientochinensis & SK710, China, CH 110015 & & & \\
\hline & KoLR & KX793096 & KX793099 & KX793102 \\
\hline auriea chujaensis & $\begin{array}{l}\text { SKD07, S Korea, Jeju-do, Jeju-si, } \\
\text { Chuja-do Island, } 33^{\circ} 56^{\prime} 38.66^{\prime \prime} \mathrm{N}, \\
126^{\circ} 18^{\prime} 47.10^{\prime \prime} \mathrm{E}, 10 \mathrm{~m} \text { alt., Kond- } \\
\text { ratyuk, S. (141138) } 22.06 .2014,\end{array}$ & & & 103 \\
\hline Franwilsia bastowii & al. $(2014 a)$ & KJ021324 & KJ021257 & KJ021284 \\
\hline ia kilcundaensis & al. $(2014 a)$ & KJ021326 & KJ021259 & KJ021286 \\
\hline Franwilsia renatae & k et al. $(2014 a)$ & KJ021329 & & KJ021289 \\
\hline Fulgensia fulgens & Ket al. $(2014 a)$ & KJ021335 & & KJ021295 \\
\hline Fulgensia cranfieldii & et al. $(2014 a)$ & KJ021333 & KJ021262 & KJ021292 \\
\hline Fulgensia poeltii & Gaya & EU639586 & & \\
\hline rrea decipioides & yuk et al. $(2013 b)$ & KF264644 & & KF264695 \\
\hline Gyalo & Gay & EU639587 & & \\
\hline Gyalolechia canariensis & al. $(2014 a)$ & KJ021332 & & \\
\hline Gyalolechia aurea & Aru & KC179434 & КС179196 & KC179530 \\
\hline Huneckia rheinigera & SK3 & KJ021222 & & \\
\hline Hunes & SK32 & KJ021336 & KJ021265 & KJ021296 \\
\hline Huned & al. $(2014 a)$ & KJ021337 & KJ021266 & KJ021297 \\
\hline indarensis & Gaya & JQ301672 & & \\
\hline Jasonhuria bogilana & $\begin{array}{l}\text { KoLRI 120454, Kondratyuk et al. } \\
(2015 d)\end{array}$ & KT220196 & KT220205 & KT220214 \\
\hline Jasonhuria bogilana & $\begin{array}{l}\text { KoLRI 120469, Kondratyuk et al. } \\
(2015 d)\end{array}$ & KT220197 & KT220206 & KT220215 \\
\hline Jasonhuria bogilana & $\begin{array}{l}\text { KoLRI 120641, Kondratyuk et al. } \\
(2015 d)\end{array}$ & KT220198 & KT220207 & KT220216 \\
\hline Jasonhuria bogilana & $\begin{array}{l}\text { KoLRI 120647, Kondratyuk et al. } \\
(2015 d)\end{array}$ & KT220199 & KT220208 & KT220217 \\
\hline Josefp & Kondratyuk et al. (2013b) & KF264645 & KF264673 & KF264696 \\
\hline Kaernefia kaernefeltii & SK921, Kondratyuk et al. (2013b) & KF264652 & KF264680 & KF264703 \\
\hline Leproplaca obliterans & Arup et al. (2013a) & KC179449 & KC179207 & \\
\hline Leproplaca xantholyta & Arul & KC179451 & KC179208 & KC179542 \\
\hline Leproplaca xantholyta & Gaya et al. (2012) & JQ301670 & JQ301565 & \\
\hline Loekoes & $\begin{array}{l}\text { KoLRI 120511, Kondratyuk et al. } \\
(2015 d)\end{array}$ & KT220200 & KT220209 & KT220218 \\
\hline Loekoesia austrocoreana & $\begin{array}{l}\text { KoLRI 120523, Kondratyuk et al. } \\
(2015 d)\end{array}$ & KT220201 & KT220210 & KT220219 \\
\hline Loekoesia austrocoreana & SK261, Kondratyuk et al. (2015d) & KT220202 & KT220211 & KT220220 \\
\hline Marchantiana maulensis & al. $(2014 a)$ & KJ023182 & KJ023184 & \\
\hline Marchantiana occidentalis & al. $(2014 a)$ & KJ021227 & KJ021268 & KJ021303 \\
\hline Marchantiana occidentalis & SK982, Kondratyuk et al. (2014a) & KJ021228 & KJ021269 & KJ021304 \\
\hline Mikhtomia gordejevii & $\begin{array}{l}\text { SK80515, Kondratyuk et al. } \\
(2014 a)\end{array}$ & KJ021231 & & KJ021307 \\
\hline
\end{tabular}


Table 1 (continued)

\begin{tabular}{|c|c|c|c|c|}
\hline Species name & Voucher details / references & ITS & LSU & mt DNA \\
\hline Mikhtomia gordejevii & $\begin{array}{l}\text { SK80646, Kondratyuk et al. } \\
(2014 a)\end{array}$ & KJ021232 & & KJ021308 \\
\hline Mikhtomia oxnerii & $\begin{array}{l}\text { SK90117, Kondratyuk et al. } \\
(2014 a)\end{array}$ & KJ021233 & & KJ021311 \\
\hline Mikhtomia oxnerii & $\begin{array}{l}\text { SK90755, Kondratyuk et al. } \\
(2014 a)\end{array}$ & KJ021234 & & KJ021312 \\
\hline Olegblumia demissa & SK C65, Kondratyuk et al. $(2015 d)$ & KT220203 & KT220212 & KT220221 \\
\hline Olegblumia demissa & Arup and Grube (1999) & AF353960 & & \\
\hline Olegblumia demissa & Arup et al. $(2013 a)$ & & KC179172 & KC179505 \\
\hline Olegblumia demissa & Arup and Grube (1999) & AF353962 & & \\
\hline Olegblumia demissa & Arup and Grube (1999) & AF353961 & & \\
\hline Oxneria alfredii & FNM 152, Fedorenko et al. (2009) & FNM 152 & & \\
\hline Pyrenodesmia alociza & SK747, Kondratyuk et al. (2014a) & KJ021239 & & KJ021313 \\
\hline Pyrenodesmia teicholyta & Vondrák et al. (2012) & JN641791 & & \\
\hline Pyrenodesmia teicholyta & Arup et al. (2013a) & & KC179176 & \\
\hline Pyrenodesmia variabilis & Gaya et al. (2003) & AY233224 & & \\
\hline Rufoplaca scotoplaca & Arup et al. $(2013 a)$ & KC179457 & KC179235 & KC179573 \\
\hline Rufoplaca tristiuscula & Arup et al. $(2013 a)$ & KC179460 & KC179237 & KC179575 \\
\hline Seirophora californica & Arup et al. $(2013 a)$ & KC179643 & & \\
\hline Seirophora lacunosa & SK B07, Kondratyuk et al. (2015d) & KT220204 & KT220213 & KT220222 \\
\hline Seirophora villosa & Martin and Winka (2000) & AF098407 & & \\
\hline Teloschistes flavicans & $\begin{array}{l}\text { FNM-139, Fedorenko et al. } \\
(2009,2012)\end{array}$ & EU681363 & & EU680955 \\
\hline Teloschistes flavicans & Arup et al. (2013a) & KC179317 & KC179255 & KC179594 \\
\hline Usnochroma carphinea & Arup et al. $(2013 a)$ & KC179468 & KC179259 & KC179598 \\
\hline Usnochroma carphinea & & EU639595 & & \\
\hline Usnochroma carphinea & Gaya et al. (2012) & & JQ301548 & \\
\hline Usnochroma scoriophila & Gaya et al. (2012) & JQ301664 & JQ301560 & \\
\hline Variospora alpigena & Arup and Grube (1999) & AF353956 & & \\
\hline Variospora latzelii & Vondrák et al. (unpubl.) & JN813418 & & \\
\hline Variospora velana & Arup et al. $(2013 a)$ & KC179476 & KC179265 & KC179605 \\
\hline Xanthocarpia ochracea & SK637, Kondratyuk et al. (2014b) & KJ133483 & & \\
\hline Xanthoria parietina & $\begin{array}{l}\text { FNM-177, Fedorenko et al. } \\
(2009,2012)\end{array}$ & EU681289 & & EU680868 \\
\hline Xanthoria parietina & Gaya et al. (2012) & & JQ301589 & \\
\hline Yoshimuria cerussata & SK768, Kondratyuk et al. (2014a) & KJ021248 & & \\
\hline Yoshimuria galbina & SK704, Kondratyuk et al. (2014a) & & & KJ023197 \\
\hline Yoshimuria spodoplaca & SK725, Kondratyuk et al. (2014a) & KJ021249 & & KJ023194 \\
\hline
\end{tabular}

\section{New combinations}

Fauriea chujaensis (S. Y. Kondr., L. Lőkös et Hur) S. Y. Kondr., L. Lőkös, J. Kim, A. S. Kondratiuk, S.-O. Oh et J.-S. Hur., comb. nova [Mycobank no.: MB 817963] - Basionym: Caloplaca chujaensis S. Y. Kondr., L. Lőkös et J.-S. Hur in Kondratyuk et al. Acta Bot. Hung. 57(1-2): 86 (2015). 


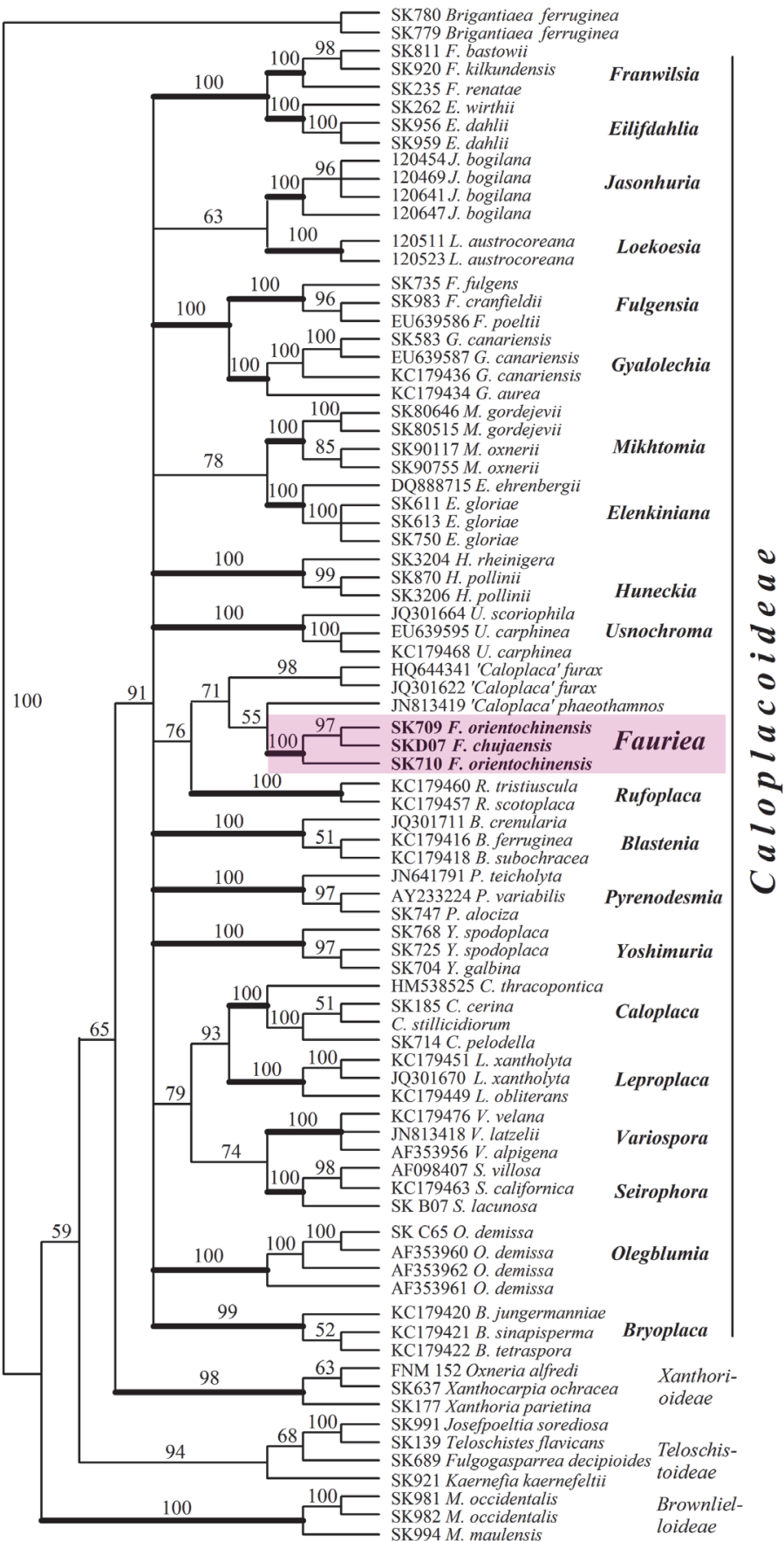

Fig. 3. Phylogenetic tree of the caloplacoid lichens based on combined data set 
Type: Republic of Korea. Jeju-do Province: Jeju-si, Chuja-do Island, Chuja-myeon, small gorge with steep shaded walls at Muk-ri, along the western coast. Lat.: $33^{\circ} 56^{\prime} 38.66^{\prime \prime} \mathrm{N}$; Long.: $126^{\circ} 18^{\prime} 47.10^{\prime \prime}$ E; Alt.: ca $10 \mathrm{~m}$ a.s.l., on siliceous rock, growing together with Caloplaca siderites. Coll.: Kondratyuk, S. Y. [site 15], L. Lőkös and J. Halda (141135), 22.06.2014 (KoLRI 023695 - holotype).

Specimen of Fauriea chujaensis examined: China, Shandong Prov., Rongcheng Co., Mt Chengshantou, on rock, growing together with Ramalina sekika. Lat.: $37^{\circ} 25^{\prime} 03.0^{\prime \prime}$ N; Long.: $122^{\circ} 40^{\prime} 38.3^{\prime \prime}$ E; Alt.: 20 m a.s.l. Coll.: Wang, X. Y. and Hur, J.-S. (CH-110018), 18.07.2011 (KoLRI 013960 sub Ramalina sekika). - It is for the first timer recorded for China.

As far the name Tayloriella S. Y. Kondr., Kärnefelt., A. Thell, Elix et Hur (Kondratyuk et al. 2015b) found to be a later homonym of the genus Tayloriella Kylin (Rhodomebaceae, Rhodophyta), a new name Tayloriellina for this lichen genus of the subfamily Brownlielloideae as well as new combination for type species of this genus is consequently proposed.

Tayloriellina S. Y. Kondr., Kärnefelt., A. Thell, Elix et Hur, nom. nov. [Mycobank no.: MB 817964] - Syn.: Tayloriella S. Y. Kondr., Kärnefelt., A. Thell, Elix et Hur, in Kondratyuk, Kärnefelt., Thell, Elix, Kim, Kondratiuk et Hur, Acta Bot. Hung. 57(3-4): 336 (2015), nom. inval. non Tayloriella Kylin (Rhodomebaceae, Rhodophyta). - Type species: Tayloriellina erythrosticta (Taylor) S. Y. Kondr., Kärnefelt., A. Thell, Elix, J. Kim, A. S. Kondr. et Hur.

Tayloriellina erythrosticta (Taylor) S. Y. Kondr., Kärnefelt., A. Thell, Elix, J. Kim, A. S. Kondr. et Hur, comb. nova [Mycobank no.: MB 817965] Basionym: Lecanora erythrosticta Taylor, London J. Bot. 6: 161 (1847). - Syn.: Caloplaca erythtosticta (Taylor) Zahlbr., Cat. Lich. Univers. 7: 116 (1930) [1931]. $\equiv$ Tayloriella erythrosticta (Taylor) S. Y. Kondr., Kärnefelt., A. Thell, Elix, J. Kim, A. S. Kondr. et Hur, in Kondratyuk, Kärnefelt., Thell, Elix, Kim, Kondratiuk et Hur, Acta Bot. Hung. 57(3-4): 341 (2015), nom. inval.

\section{CONCLUSIONS}

The further data on molecular characters of crustose members of the Teloschistaceae will allow clarifying species diversity of genus described here, as well as its diagnostic characters.

Status of a number of phylogenetical branches, which are positioned within the clades Mikhtomia s. lat., Variospora s. lat., and Seirophora s. lat., will be especially discussed in our next paper on taxonomy and molecular phylogeny of the caloplacoid lichens. 
Acknowledgements - This work was supported in part by The Ministry of Education and Science of Ukraine (M/90-2015 and M/34-2016) and by Korean Brian Pool Programm (161S4-3-1659) for SK, and by The Forest Science and Technology Projects (No. S111212L030100) provided by the Korea Forest Service for JSH.

\section{REFERENCES}

Aptroot, A. and Cáceres, M. E. S. (2016): Two new lecanoroid Caloplaca (Teloschistaceae) species from gneiss inselbergs in equatorial Brazil, with a key to tropical lecanoroid species of Caloplaca s. lat. - Lichenologist 48(3): 201-207. http://dx.doi.org/10.1017/ s0024282916000049

Arup, U. and Grube, M. (1999): Where does Lecanora demissa (Ascomycota, Lecanorales) belong? - Lichenologist 31: 419-430. http://dx.doi.org/10.1017/s0024282999000584

Arup, U., Søchting, U. and Frödén, P. (2013a): A new taxonomy of the family Teloschistaceae. - Nord. J. Bot. 31(1): 16-83. http://dx.doi.org/10.1111/j.1756-1051.2013.00062.x

Arup, U., Søchting, U. and Frödén, P. (2013b): Addendum to 'A new taxonomy of the family Teloschistaceae'. - Nord. J. Bot. 31: 256. http://dx.doi.org/10.1111/j.17561051.2013.00295.x

Ekman, S. (1999): PCR optimization and troubleshooting, with special reference to the amplification of ribosomal DNA in lichenized fungi. - Lichenologist 31(5): 517-531. http://dx.doi.org/10.1017/s0024282999000675

Fedorenko, N. M., Stenroos, S., Thell, A., Kärnefelt, I. and Kondratyuk, S. Y. (2009): A phylogenetic analysis of xanthorioid lichens (Teloschistaceae, Ascomycota) based on ITS and mtSSU sequences. - Bibl. Lichenol. 100: 49-84.

Fedorenko, N. M., Stenroos, S., Thell, A., Kärnefelt, I., Elix, J. A., Hur, J.-S. and Kondratyuk, S. Y. (2012): Molecular phylogeny of xanthorioid lichens (Teloschistaceae, Ascomycota), with notes on their morphology. - Bibl. Lichenol. 108: 45-64.

Gardes, M. and Bruns, T. D. (1993): ITS primers with enhanced specificity for basidiomycetes - application to the identification of mycorrhizae and rusts. - Mol. Ecol. 2: 113118. http://dx.doi.org/10.1111/j.1365-294x.1993.tb00005.x

Gaya, E., Lutzoni, F., Zoller, S. and Navarro-Rosinés, P. (2003): Phylogenetic study of Fulgensia and allied Caloplaca and Xanthoria species (Teloschistaceae, lichen-forming Ascomycota). - Amer. J. Bot. 90(7): 1095-1103. http://dx.doi.org/10.3732/ajb.90.7.1095

Gaya, E., Navarro-Rosinés, P., Llimona, X., Hladun, N. and Lutzoni, F. (2008): Phylogenetic reassessment of the Teloschistaceae (lichen-forming Ascomycota, Lecanoromycetes). - Mycol. Res. 112(5): 528-546. http://dx.doi.org/10.1016/j.mycres.2007.11.005

Gaya, E., Högnabba, F., Holguin, Á., Molnár, K., Fernández-Brime, S., Stenroos, S., Arup, U., Søchting, U., van den Boom, P., Lücking, R., Sipman, H. J. M. and Lutzoni, F. (2012): Implementing a cumulative supermatrix approach for a comprehensive phylogentic study of the Teloschistales (Pezizomycotina, Ascomycota). - Mol. Phyl. Evol. 63: 374-387. http://dx.doi.org/10.1016/j.ympev.2012.01.012

Gaya, E., Fernández-Brime, S., Vargas, R., Lachlan, R. F., Gueidan, C., Ramírez-Mejía, M. and Lutzoni, F. (2015): The adaptive radiation of lichen-forming Teloschistaceae is associated with sunscreening pigments and a bark-to-rock substrate shift. - Proc. Nat. Acad. Sci. USA 112(37): 11600-11605. http://dx.doi.org/10.1073/pnas.1507072112 
Kärnefelt, I. (1989): Morphology and phylogeny in the Teloschistales. - Cryptog. Bot. 1: 147-203.

Kondratyuk, S. Y., Lőkös, L., Zarei-Darki, B., Haji Moniri, M., Tchabanenko, S. I., Galanina, I., Yakovchenko, L., Hooshmand, F., Ezhkin, A. K. and Hur, J.-S. (2013a): Five new Caloplaca species (Teloschistaceae, Ascomycota) from Asia. - Acta Bot. Hung. 55(1-2): 41-60. http://dx.doi.org/10.1556/abot.55.2013.1-2.4

Kondratyuk, S. Y., Jeong, M.-H., Yu, N. H., Kärnefelt, I., Thell, A., Elix, J. A., Kim, J., Kondratyuk, A. S. and Hur, J.-S. (2013b): Four new genera of Teloschistoid lichens (Teloschistaceae, Ascomycota) based on molecular phylogeny. - Acta Bot. Hung. 55(3-4): 251-274. http://dx.doi.org/10.1556/abot.55.2013.3-4.8

Kondratyuk, S. Y., Jeong, M.-H., Yu, N. N., Kärnefelt, I., Thell, A., Elix, J. A., Kim, J., Kondratiuk, A. S. and Hur, J.-S. (2014a): A revised taxonomy for the subfamily Caloplacoideae (Teloschistaceae, Ascomycota) based on molecular phylogeny. - Acta Bot. Hung. 56(1-2): 93-123. http://dx.doi.org/10.1556/abot.56.2014.1-2.10

Kondratyuk, S. Y., Kärnefelt, I., Thell, A., Elix, J. A., Kim, J., Jeong, M.-H., Yu, N. H., Kondratiuk, A. S. and Hur, J.-S. (2014b): A revised taxonomy of the subfamily Xanthorioideae (Teloschistaceae, Ascomycota) based on molecular phylogeny. - Acta Bot. Hung. 56(1-2): 141-178. http://dx.doi.org/10.1556/abot.56.2014.1-2.12

Kondratyuk, S. Y., Lőkös, L., Farkas, E., Oh, S.-O. and Hur, J.-S. (2015a): New and noteworthy lichen-forming and lichenicolous fungi, 2. - Acta Bot. Hung. 57(1-2): 77-141. http://dx.doi.org/10.1556/abot.57.2015.1-2.10

Kondratyuk, S. Y., Kärnefelt, I., Thell, A., Elix, J. A., Kim, J., Kondratiuk, A. S. and Hur, J.-S. (2015b): Brownlielloideae, a new subfamily in the Teloschistaceae (Lecanoromycetes, Ascomycota). - Acta Bot. Hung. 57(3-4): 321-341. http://dx.doi.org/10.1556/ 034.57.2015.3-4.6

Kondratyuk, S. Y., Lőkös, L., Kim, J. A., Kondratiuk, A. S., Jeong, M.-H., Jang, S. H., Oh, S.-O. and Hur, J.-S. (2015c): Three new monotypic genera of the Caloplacoid lichens (Teloschistaceae, lichen-forming Ascomycetes). - Mycobiology 43(3): 195-202. http:// dx.doi.org/10.5941/myco.2015.43.3.195

Kondratyuk, S. Y., Kim, J. A., Yu, N.-H., Jeong, M.-H., Jang, S. H., Kondratiuk, A. S., Zarei-Darki, B. and Hur, J.-S. (2015d): Zeroviella, a new genus of xanthorioid lichens (Teloschistaceae, Ascomycota) proved by three gene phylogeny. - Ukr. Bot. J. 72(6): 574-584. http://dx.doi.org/10.15407/ukrbotj72.06.574

Kondratyuk, S. Y., Lőkös, L., Halda, J. P., Upreti, D. K., Mishra, G. K., Haji Moniri, M., Farkas, E., Park, J. S., Lee, B. G., Liu, D., Woo, J. J., Jayalal, R. G. U., Oh, S.-O. and Hur, J.-S. (2016): New and noteworthy lichen-forming and lichenicolous fungi 5. - Acta Bot. Hung. 58(3-4): 319-396. http://dx.doi.org/10.1556/ 034.57.2016.3-4.7

Martin, M. P. and Winka, K. (2000): Alternative methods of extracting and amplifying DNA from lichens. - Lichenologist 32: 189-196. http://dx.doi.org/10.1006/lich.1999.0254

Orange, A., James, P. W. and White, F. J. (2010): Microchemical methods for the identification of lichens. 2nd ed. - British Lichen Society, London, 101 pp.

Søchting, U. and Figueras, G. (2006): Caloplaca lenae sp. nov. and other Caloplaca species with caloploicin and vicanicin. - Lichenologist 39(1): 7-14. http://dx.doi.org/10.1017/ s0024282907006299

Søchting, U., Sogaard, M. Z., Elix, J. A., Arup, U., Elvebakk, A. and Sancho, L. G. (2014a): Catenarina (Teloschistaceae, Ascomycota), a new Southern Hemisphere genus with 7-chlorocatenarin. - Lichenologist 46(2): 175-187. http://dx.doi.org/10.1017/ s002428291300087x 
Søchting, U., Garrido-Benavent, I., Seppelt, R., Castello, M., Pérez-Ortega, S., De Los Ríos Murillo, A., Sancho, L. G., Frödén, P. and Arup, U. (2014b): Charcotiana and Amundsenia, two new genera in Teloschistaceae (lichenized Ascomycota, subfamily Xanthorioideae) hosting two new species from continental Antarctica, and Austroplaca frigida, a new name for a continental Antarctic species. - Lichenologist 46(6): 763-782. http://dx.doi.org/10.1017/s0024282914000395

Tamura, K., Peterson, D., Peterson, N., Stecher, G., Nei, M. and Kumar, S. (2011): MEGA5: molecular evolutionary genetics analysis using maximum likelihood, evolutionary distance, and maximum parsimony methods. - Mol. Biol. Evol. 28: 2731-2739. http:// dx.doi.org/10.1093/molbev/msr121

Vilgalys, R. and Hester, M. (1990): Rapid genetic identification and mapping of enzymatically amplified ribosomal DNA from several Cryptococcus species. - J. Bacteriol. 172(8): 4238-4246.

Vondrák, J., Soun, J., Vondráková, O., Fryday, A. M., Khodosovtsev, A. and Davydov, E. (2012): Absence of anthraquinone pigments is paraphyletic and a phylogenetically unreliable character in the Teloschistaceae. - Lichenologist 44: 401-418. http://dx.doi. org/10.1017/s0024282911000843

White, T. J., Bruns, T., Lee, S. and Taylor, J. (1990): Amplification and direct sequencing of fungal ribosomal RNA genes for phylogenetics. - PCR Protocols 38: 315-322. http:// dx.doi.org/10.1016/b978-0-12-372180-8.50042-1 